\title{
KONSUMSI EKSTRAK DAUN KELOR DALAM MENINGKATKAN KADAR HEMOGLOBIN PADA IBU HAMIL
}

\author{
Tri Hartati ${ }^{1}$,Sunarsih ${ }^{2}$ \\ ${ }^{1}$ Mahasiswa Program Studi Kebidanan, Universitas Malahayati
Email: $17340143 @$ malahayati.ac.id
${ }^{2}$ Dosen Program Studi Kebidanan, Universitas Malahayati
Email :sunarsih@malahayati.ac.id
}

ABSTRACT: CONSUMING OF MORINGA LEAF EXTRACT IN INCREASING HEMOGLOBIN LEVEL TOWARD PREGNANT WOMAN.

Introduction:Anemia rate on pregnancy in Indonesia showed quite high level that was $3,8 \%$ on the first trimester, $13,6 \%$ on second trimester and $24,8 \%$ on the third trimester. Most of anemia whom suffered was lack of zinc which can be resolved through giving nutrition regularly and nutritive enhancement.

Purpose:The purpose of this research was in knowing the influence in consuming of moringa leaf extract through increasing hemoglobin level toward pregnant woman.

Method:This was a quantitative with Quasi Experimental research design and one group pretest- posttest design approach. Population in this research was pregnant woman on third semester. The amount of sample was 33 people whom gotten by using Purposive sampling technique. This research was done in M.Mataram Public Health Center, West Lampung regency,on February-August 2018. Data collecting used observation sheet and Hemoglobin Test. Bivariate data analysis used T-Test.

Result: An average of hemoglobin level the third trimester pregnant woman before given Moringa Leaf extracts with mean 9.642 and deviation standard 0 . 6103. After consuming Moringa Leaf extracts was gotten an average hemoglobin level pregnant woman, 10.648 and deviation standard, 0.9582. The result of statistic test was gotten Value $p$-Value $0,000<0,005$

Conclusion: There was influence in consuming Moringa Leaf extracts toward enhancement of hemoglobin level on pregnant woman. Then for midwife gives counseling to pregnant woman regularly about the importance of consuming meal which is rich Fe content and Vitamin C such as moringa leaf.

Key Words: Moringa Leaf, Hemoglobin Level, Pregnant Woman

\section{INTISARI: KONSUMSI EKSTRAK DAUN KELOR DALAM MENINGKATKAN KADAR HB PADA IBU HAMIL}

Latar Belakang: Angka kejadian anemia pada kehamilan di Indonesia menunjukkan nilai yang cukup tinggi yaitu 3,8\% pada trimester I, 13,6\% pada trimester II dan $24,8 \%$ pada trimester III. Kebanyakan anemia yang diderita adalah kekurangan zat besi yang dapat diatasi melalui pemberian zat gizi secara teratur dan peningkatan gizi.

Tujuan: Tujuan penelitian untuk mengetahui pengaruh konsumsi ekstrak daun kelor dengan meningkatkan kadar $\mathrm{Hb}$ pada ibu hamil.

Metode Penelitian: Jenis penelitian ini adalah kuantitatif dengan desain penelitian Quasi Eksperimental dan pendekatan one group pretes-postes design. Populasi dalam penelitian adalah ibu hamil trimester III. Sampel berjumlah 33 
orang yang didapatkan dengan menggunakan teknik Purposive sampling. Penelitian telah dilakukan di Puskesmas M. Mataram Kab. Lampung Selatan pada Februari - Agustus 2018. Pengumpulan data menggunakan lembar observasi dan HB Test. Analisa data bivariate menggunakan uji t-test. Hasil: Rata-rata kadar Hemoglobin ibu hamil trimester III sebelum diberikan ekstrak daun kelor dengan Mean 9.642 dan Standar Deviasi 0.6103. Sesudah mengkonsumsi ekstrak daun kelor didapatkan rata - rata kadar HB ibu hamil sebesar 10.648 dan Standar Deviasi 0.9582. Hasil uji statistic didapatkan nilai $\mathrm{p}$ - value $0,000<0,005$

Kesimpulan: ada pengaruh konsumsi ekstrak daun kelor terhadap peningkatan kadar hemoglobin ibu hamil. Kepada bidan agar rutin memberikan penyuluhan kepada ibu hamil, tentang pentingnya mengkonsumsi makanan yang kayak kandungan Fe dan Vitamin C seperti daun kelor.

Kata Kunci : :Daun Kelor, Kadar Hb, Ibu Hamil

\section{PENDAHULUAN:}

Anemia merupakan kondisi berkurangnya sel darah merah (eritrosit) dalam sirkulasi darah atau massa hemoglobin $(\mathrm{Hb})$ sehingga tidak mampu memenuhi fungsi sebagai pembawa oksigen ke selutuh jaringan (Astuti, R. Y., \& Ertiana, D. 2018)

Masa kehamilan merupakan masa rentan terjadi anemia. Anemia yang paling sering dijumpai pada kehamilan adalah anemia akibat kekurangan zat besi. Pada masa kehamilan terjadi penambahan volume darah (hidremia atau hemodolusi), akan tetapi bertambahnya sel - sel darah kurang dibandingkan dengan bertambahnya plasma sehingga terjadi pengenceran darah. Selain itu, beberapa penyebab anemia pada kehamilan yaitu karena zat besi yang masuk melalui makanan tidak mencukupi kebutuhan, saat hamil kebutuhan zat - zat makanan bertambah untuk memproduksi sel darah merah yang lebih banyak untuk ibu dan janin yang dikandungnya, dan pada saat hamil terjadi perubahan - perubahan dalam darah dan sumsum tulang. (Simbolon, D.2018).

Anemia pada ibu hamil dihubungkan dengan meningkatnya kelahiran prematur, kematian ibu dan anak dan penyakit infeksi.
Anemia defisiensi besi pada ibu dapat mempengaruhi pertumbuhan dan perkembangan janin/bayi saat kehamilan maupun setelahnya. Hasil Riskesdas 2013 menyatakan bahwa anemia terjadi pada $37,1 \%$ ibu hamil di Indonesia, 36,4\% ibu hamil perkotaan dan 37, 8\% ibu hamil di perdesaan (Indonesia, K. K. R. 2017).

Terapi utama pada anemia adalah pemberian suplemen $\mathrm{Fe}$ setiap hari $200 \mathrm{mg}$, jika $\mathrm{Hb}<5-6$ gr\% maka perlu dilakkan transfuse darah (Manuaba, 2007). Ibu hamil yang mengalami anemia defisiensi besi sangat disarankan melakukan diet makanan yang mengandung besi dan pemenuhan nutrisi yang adekuat (Astuti R.Y \& Ertiana, 2018). Makanan yang baik dikonsumsi sehari-hari diantanya yaitu bayam, daun katuk, brokoli, hati ayam dan kacang-kacangan. Selain itu, olahan makanan yang banyak mengandung zat besi salah satunya juga terdapat pada daun kelor (Handayani, L.2003).

Daun kelor adalah tanaman yang kaya akan sumber protein, zat besi, vitamin $C$, dan nutrisi penting lainnya. Daun kelor memiliki manfaat yang besar, murah dan mudah didapatlan. Dalam $100 \mathrm{~g}$ daun kelor kering mengandung protein sebanyak $27,1 \mathrm{~g}$, lemak $2,3 \mathrm{~g}$, vitamin A sebanyak $18,9 \mathrm{mg}$, thiamin 2,64 $\mathrm{mg}$, Riboflavin 20,05 mg, Vitamin C 
$17,3 \mathrm{mg}$, kalsium 2,003 mg, kalori sebanyak 205 kal, karbohidrat 38,2 g, Zat Besi 28,2g, Zinc (seng) 3,29 $\mathrm{mg}$ dan zat gizi laiinya. Beragam perbandingan pada daun kelor kering, yaitu daun kelor kering sama dengan $1 / 2$ kali vitamin $C$ pada jeruk segar, sama dengan 10 kali vitamin A pada wortel, 9 kali protein pada yoghurt serta 25 kali sat besi pada bayam. ( Hendarto, D.2019)

Penelitian dengan judul "efektivitas suplementasi bubuk daun kelor (moringa oleifera) terhadap peningkatan kadar hemoglobin pada ibu hamil yang menderita anemia" Hasil uji hipotesis komparatif dengan uji Wilcoxon antara kadar $\mathrm{Hb}$ sebelum dan sesudah perlakuan diperoleh nilai significancy $0,000(p<0,05)$, sehingga dapat disimpulkan bahwa terdapat perbedaan yang bermakna kadar $\mathrm{Hb}$ antara sebelum perlakuan dan sesudah perlakuan (Ponomban dkk, 2013).

Penelitian lain di SMU Muhammadiyah Kupang dengan menggunakan daun kelor yang dibuat dalam bentuk ekstrak kemudian dikemas dalam bentuk kapsul, sehingga mudah dikonsumsi dan tahan lama. Intervensi dilakukan terhadap 60 responden yang dibagi menjadi 2 yaitu 30 kelompok kontrol dan 30 kelompok intervensi. Hasil penelitian adalah pemberian ekstrak daun kelor pada remaja putri dapat meningkatkan kadar hemoglobin (Yulianti, H., Hadju, V., \& Alasiry, E. 2016)

Berdasarkan hasil perbandingan data cakupan pemberian tablet $\mathrm{Fe} 3$, Puskesmas Tanjung Bintang, telah berhasil melakukan sebaran Fe3 terhadap ibu hamil, sedangkan Puskesmas $M$. Mataram, telah berupaya memberikan cakupan $\mathrm{Fe} 3$ dengan baik, terhadap seluruh ibu hamil yang didata di Puskesmas tersebut, akan tetapi kejadian anemia lebih banyak terjadi di Puskesmas M. Mataram, dengan perbandingan 65 orang mengalami anemia sedang dan berat, dan pada Puskesmas Tanjung Bintang terdapat 34 orang yang mengalami anemia.

Berdasarkan pengambilan data awal yang dilakukan di Puskesmas M Mataram pada bulan februari tahun 2018 dengan melakukan pemeriksaan $\mathrm{HB}$ gratis secara acak terdapat 6 orang memiliki kadar $\mathrm{Hb}<10$ gr\%. Kondisi ibu hamil terlihat cukup sehat, berdasarkan wawancara mendala sejumlah ibu hamil mengatakan tidak rutin mengkonsumsi tablet $\mathrm{Fe}$, karna menyebabkan mual dan sering lupa.

Anemia pada kehamilan merupakan masalah nasional karena mencerminkan nilai kesejahteraan sosial ekonomi masyarakat, dan pengaruhnya sangat besar terhadap kualitas sumber daya manusia. Anemia kehamilan disebut "potential danget to mother and child", karena itulan anemia memerlukan perhatian serius dari semua pihak yang terkait dalam pelayanan kesehatan pada lini terdepan (Manuaba, 2012)

\section{METODOLOGI PENELITIAN}

Jenis penelitian ini merupakan jenis penelitian kuantitatif. Rancangan penelitian yang digunakan adalah rancangan penelitian Quasi Eksperimental dengan pendekatan one group pretest - posttest design. One Group pretest-posttest adalah desain eksperimen dengan ciri digunakan satu kelompok (one-group) eksperimen yang menerima dua kali pengukuran, sebelum diberikan treatment dan setelah treatment dilakukan (Santoso, S. 2013). Penelitian di lakukan di Puskemas M Mataram pada bulan Februari Agustus 2018. Responden dalam 
penelitian ini adalah wanita hamil dengan anemia ringan sebanyak 33 orang yang didapatkan dengan menggunakan teknik purposive sampling, dimana respoden dalam penelitian adalah respoden yang telah memenuhi kriteri inklusi yang sudah ditetapkan oleh peneliti yaitu ibu hamil yang tidak memiliki komplikasi dan memiliki kadar HB 810 gr\%.

Variabel penelitian terdiri dari variable independent yaitu ekstrak daun kelor dan variable dependen yaitu kadar Hemoglobin. Pengambilan data dilakukan secara primer (langsung). Penelitian dilakukan dengan melakukan HASIL PENELITIAN DAN PEMBAHASAN Analisis Univariat pemeriksaan HB kepada responden dengan menggunakan alat Haemo cek lalu memberikan intervensi berupa tablet serbuk kelor sebanyak $70 \mathrm{mg}$ perhari yang dikonsumsi selama 14 hari ( 2 minggu). Pada hari ke 14 (setelah konsumsi terakhir) peneliti melakukan pemeriksaan $\mathrm{HB}$ kembali.

Analisa data menggunakan program komputer, analisa univariat bertujuan untuk mengetahui distribusi frekuensi. Analisa bivariat menggunakan uji $t$ dependen. Uji dilakukan untuk melihat pengaruh ektrak daun kelor terhadap kenaikan kadar HB pada ibu hamil dengan melihat nilai $\mathrm{p}$ value.

Tabel 1

Kadar Hemoglobin Ibu Hamil

\begin{tabular}{lccccc}
\hline Kadar Hemoglobin & Mean & Min & Max & Std.Deviation & $\boldsymbol{n}$ \\
\hline Sebelum diberi ekstrak daun & 9.642 & 8.5 & 11.0 & 0.6103 & 33 \\
Sesudah diberi ekstrak daun & 10.648 & 9.0 & 12.8 & 0.9582 & 33 \\
\hline
\end{tabular}

Tabel 1 diketahui bahwa dari 33 responden mean kadar $\mathrm{Hb}$ ibu hamil sebelum diberikan ekstrak daun kelor adalah 9,642, nilai minimum 8,5 dan nilai maksimum 1.0 dengan standar deviasi 0,6103. Sedangkan mean kadar $\mathrm{Hb}$ ibu Analisis Bivariat hamil setelah diberikan ekstrak daun kelor adalah 10.648, nilai minimum 9.0 dan nilai maksimum 12.8, dengan standar deviasi 0.9582 .

Tabel 2

Pengaruh Ekstrak Daun Kelor Terhadap Kenaikan Kadar Hemoglobin

\begin{tabular}{lccccc}
\hline \multicolumn{1}{c}{ Kadar Hemoglobin } & Mean & $\begin{array}{c}\text { Beda } \\
\text { Mean }\end{array}$ & SD & $\begin{array}{c}p- \\
\text { value }\end{array}$ & $n$ \\
\hline $\begin{array}{l}\text { Sebelum diberi ekstrak daun } \\
\text { kelor }\end{array}$ & 9.642 & 1.006 & 0.8456 & 0,000 & 33 \\
$\begin{array}{l}\text { Sesudah diberi ekstrak daun } \\
\text { kelor }\end{array}$ & $\begin{array}{c}10.64 \\
8\end{array}$ & & & & \\
\hline
\end{tabular}

Berdasarkan tabel diatas, diketahui bahwa mean kadar $\mathrm{Hb}$ sebelum diberikan ekstrak daun kelor yaitu 9.641 dan mean setelah diberikan ekstrak daun kelor yaitu 10.648. Beda mean sebelum dan setelah intervensi adalah 1.006 .
Hasil uji statistik didapatkan $\mathrm{p}$ value $=0,000(<$ a 0,005) yang berarti ada pengaruh pemberian ektrak daun kelor terhadap kenaikan kadar Hemoglobin pada ibu hamil

\section{PEMBAHASAN}


Berdasarkan hasil analisa univariat diketahui bahwa dari 33 responden mean kadar $\mathrm{Hb}$ ibu hamil sebelum diberikan ekstrak daun kelor adalah 9,642, nilai minimum 8,5 dan nilai maksimum 1.0 dengan standar deviasi 0,6103 . Sedangkan mean kadar $\mathrm{Hb}$ ibu hamil setelah diberikan ekstrak daun kelor adalah 10.648, nilai minimum 9.0 dan nilai maksimum 12.8 , dengan standar deviasi 0.9582. Berdasarkan uji bivariat didapatkan perbedaan nilai mean sebesar 1.006 dan $p$ value $=0,000(<a 0,005)$ yang berarti ada pengaruh pemberian ektrak daun kelor terhadap kenaikan kadar Hemoglobin pada ibu hamil

Kadar $\mathrm{Hb}$ dalam darah merupakan cara mengetahui anemia atau tidaknya seseorang. Wanita hamil cenderung terkena anemia pada trimester ketiga. Karena, pada masa ini janin menimbun cadangan zat besi untuk dirinya sendiri sebagai persediaan bulan pertama sesudah lahir. Faktor utama penyebab anemia gizi adalah kurang cukupnya zat besi ( $\mathrm{Fe}$ ) dalam makanan sehari hari (Sinsin, I. 2013)

Kebutuhan zat besi selama kehamilan yaitu rata - rata $800 \mathrm{mg}$ $1040 \mathrm{mg} . \pm 300 \mathrm{mg}$ diperlukan untuk pertumbuhan janin, $\pm 50-75 \mathrm{mg}$ untuk pembentukan plasenta, \pm 500 $\mathrm{mg}$ digunakan untuk meningkatkan massa hemoglobin maternal/sel darah merah, $\pm 200 \mathrm{mg}$ lebih akan dieksresikan lewat usus, urin dan kulit serta $\pm 200 \mathrm{mg}$ lenyap ketika melahirkan. Perhitungan makan $3 x$ sehari atau 1000 - 2500 kalori akan menghasilkan sekitar 10 - $15 \mathrm{mg}$ zat besi perhari namun hanya 1 - $2 \mathrm{mg}$ yang diabsorpsi. Jika ibu mengkonsumsi $60 \mathrm{mg}$ zat besi, maka diharapkan 6 - $8 \mathrm{mg}$ zat besi dapat diabsorpsi, jika dikonsumsi selama 90 hari maka total zat besi yang diabsorpsi adalah sebanyak $720 \mathrm{mg}$ dan $180 \mathrm{mg}$ dari konsumsi harian ibu (Simbolon, D. 2018)
Agar tidak terjadi anemia, ibu hamil harus diberi tablet tambah darah atau mengkonsumsi sayuran. Selain itu, bisa mengkonsumsi olahan dari tanaman yang banyak mengandung zat besi, seperti bungkil kelapa, kangkung, daun talas, daun ketela rambat, daun kacang panjang, daun kelor, daun cincau, kecap, dan daun katuk. (Handayani, L. 2003). Kandungan gizi yang terdapat dalam daun kelor segar akan mengalami peningkatan (konsentrasinya) apabila dikonsumsi setelah dikeringkan dan dihaluskan dalam bentuk serbuk (tepuk). Kandungan Zat besi pada daun kelor setara sengan 25 kali zat besi yang terdapat pada bayam (Nurcahyati, E. 2014)

Sebanyak 25 gram bubuk daun kelor dikonsumsi oleh ibu yang sedang mengandung setiap hari untuk meningkatkan status gizi. Pada tahun 1997, Alternative Action For African Development (AGADA) dan Church World Service melaporkan bahwa tepung daun kelor dapat mencegah terjadinya masl nutrisi pada ibu - ibu yang sedang mengandung atau para ibu yang sedang menyusui serta anak anak mereka di kawasan Senegal Selatan. Pemberian tepung daun kelor mampu mempertahankan peningkatan bobot tubuh serta kesehatan tubuh secara menyeluruh. Para ibu yang sedang mengandung dan menyusui sembuh dari penyakit anemia dan melahirkan bayi yang berat badanya relative lebih besar. Ibu - ibu tersebut juga dapat memproduksi ASI lebih banyak (Winarno, F. 2018).

Sebuah penelitian dilakukan terhadap 15 orang remaja putri dengan metode observasi terhadap sampel sebelum dan sesudah mengkonsumsi ekstrak daun kelor, didapatkan hasil adanya perbedaan yang signifikan antara kadar hb sebelum dan sesudah pemberian 
ekstrak daun kelir dengan kesimpulan yang didapatkan bahwa ekstrak daun kelor efektif untuk meningkatkan kadar hemoglobin remaja putri (Fauziandari, E. N. 2019).

Penelitian lain yang memanfaatkan ektrak daun kelor dengan judul Pengaruh ekstrak daun kelor terhadap peningkatan kadar hemoglobin ibu hamil trimester 2 dan 3 di puskesmas semanu $I$. Penelitian dilakukan pada 32 reponden. Hasilnya berdasarkan uji Paired t-test menunjukkan nilai $p$ value $=0,000<0,05$ yang berarti ada pengaruh peningkatan kadar $\mathrm{Hb}$ sebelum dan setelah konsumsi daun kelor pada ibu hamil di wilayah kerja Puskesmas Semanu I Gunungkidul (Rahmawati, M., \& Daryanti, M. S. 2017)

Ibu hamil membutuhkan zat besi dua kali lebih banyak di banding wanita yang tidak hamil, zat besi pada ibu hamil dapat berpengaruh terhadap kadar hemoglobin yang berfungsi mengikat dan membawa oksigen kejaringan tubuh dan memasok oksigen kejanin. Untuk memenuhi kebutuhan zat besi selama kehamilan maka ibu hamil mendapatkan terapi tablet tambah darah (Fe) sebanyak 90 tablet selama hamil. Namun itu saja tidak cukup, terpenuhinya zat besi dapat ditunjang dengan memperhatikan nutrisi yaitu dengan mengkonsumsi makanan yang kaya akan kandungan zat besi. Salah satu sumber makanan yang kaya zat besi adalah daun kelor.

Kandungan zat besi dalam 100 gram daun kelor sebanyak 28,2 gr. Konsumsi daun kelor minimal 25 mg perhari diharapkan dapat memenuhi $7,05 \mathrm{mg}$ zat besi dalam tubuh ibu. Jika konsumsi selama 30 hari maka diharapkan dapat menyumbang $211,5 \mathrm{mg}$. Terapi tablet tambah darah yang diimbangi dengan konsumsi daun kelor dapat memenuhi kebutuhan zat besi secara maksimal. Sehingga ibu hamil memiliki kadar hemoglobin dalam jumlah yang cukup. Ibu hamil dapat terhindar dari anemia dan dampakdampak lain yang ditimbulkannya.

\section{KESIMPULAN \\ Ada pengaruh pemberian} ektrak daun kelor terhadap kenaikan kadar Hemoglobin pada ibu hamil dengan $p$ value $=0,000(<a, 0,005)$

\section{SARAN}

Daun kelor salah satu makanan yang kaya gizi terutama Zat Besi yang berguna meningkatkan kadar $\mathrm{Hb}$ dalam darah. Sangat penting bagi tenaga kesehatan agar memberikan edukasi kepada setiap ibu hamil untuk dapat meningkatkan asupan zat besi dengan memanfatkan daun kelor. Selain mudah didapatkan daun kelor juga minim efek samping.

\section{DAFTAR PUSTAKA}

Astuti, R. Y., \& Ertiana, D. (2018). Anemia dalam Kehamilan. Pustaka Abadi.

Fauziandari, E. N. (2019). EFEKTIFITAS EKSTRAK DAUN KELOR TERHADAP PENINGKATAN KADAR HEMOGLOBIN PADA REMAJA PUTRI. Jurnal Kesehatan Karya Husada, 7(2), 24-29.

Handayani, L. (2003). Tanaman Obat Untuk Masa Kehamilan dan Pasca Melahirkan. Agromedia Pustaka. Jakarta.

Hendarto, D.(2019). Khasiat Jitu Daun Kelor dan Sirih Merah Tumpas Penyakit. LAKSANA.

Indonesia, K. K. R. (2017). Data dan Informasi Profil Kesehatan Indonesia 2016. Pusat Data dan Informasi Kementrian Keshatan RI, 119-21.

Ponomban, S. S., Walalangi, R., \& Harikedua, V. T. (2013). Efektivitas suplementasi bubuk 
daun kelor (moringa oleifera) terhadap peningkatan kadar hemoglobin pada ibu hamil yang menderita anemia. Jurnal Gizido, 5(1), 36-44.

Manuaba, I. B. G., Manuaba, I. C., \& Manuaba, I. B. G. F. (2007). Pengantar kuliah obstetri. Jakarta: EGC, 450-55.

Manuaba, I. B. G., Manuaba, I. B. G. F., \& Manuaba, I. B. G. (2012). Ilmu Kebidanan, Penyakit Kandungan dan KB untuk Pendidikan Bidan. Jakarta: EGC, 421-424.

Nurcahyati, E. (2014). Khasiat Dahsyat Daun Kelor. Jakarta: Jendela Sehat.

Rahmawati, M., \& Daryanti, M. S. (2017). PENGARUH EKSTRAK DAUN KELOR TERHADAP PENINGKATAN KADAR HEMOGLOBINIBU HAMIL $\begin{array}{lllll}\text { TRIMESTER } & 2 & \text { DAN } & 3 & \text { DI }\end{array}$ PUSKESMAS SEMANU I.

Santoso, S. (2013). Kupas tuntas riset eksperimen dengan excel 2007 dan minitab 15. Elex Media Komputindo.

Sinsin, L. (2013). Masa Kehamilan \& Persalinan. Elex Media Komputindo.

Simbolon, D. (2018). Modul Edukasi Gizi Pencegahan dan Penanggulangan Kurang Energi Kronik (Kek) dan Anemia Pada Ibu Hamil. Deepublish.

Winarno, F. (2018). Tanaman Kelor (Moringa oleifera): Nilai Gizi, Manfaat, dan Potensi Usaha. Jakarta: Gramedia Pustaka Utama.

Yulianti, H., Hadju, V., \& Alasiry, E. (2016). Pengaruh Ekstrak Daun Kelor Terhadap Peningkatan Kadar Hemoglobin pada Remaja Putri di SMU Muhammadiyah Kupang. JST Kesehatan, 6(3), 399-404. 